\title{
Advances in Quality of Fastrack Watches Upon Introducing Automated Machinaries
}

\author{
J. Kannan, D. Venkatrama Raju
}

\begin{abstract}
Today Fast track provides the young at heart a wide range of products. They put on pockets, belts, wallets and even wristbands from watches and sunglasses. Watches There are several collections among the Fast track watches that can be found. Every collection refers to a certain theme that is present in that collection in each of the designs. The New collection means all the latest models that Fast track is introducing, while there are the Grunge, Hip Hop, Neon, Digital Fashion, Aluminum, Color Play, Bikers, Army and others, each with their distinct watch range.
\end{abstract} Place

Keywords: Marketing Theories, Purchasing Trend, Market

\section{INTRODUCTION}

Fast track is the brand that is part of the Titan brand for the young generation. Many brands have vice lines targeting a separate population segment. It helps to maintain a unique identity for each brand and also helps to differentiate between the focus areas for the different brands. In India, therefore, Titan is a company that belongs to the renowned Tata group and has launched Fast track, which mainly serves the young generation[1]-[3]. When a brand targets the youth, it needs to continue to adapt and reinvent itself in order to stay in touch with the current market trends that draw urban youth. Similarly, Fast track is one such brand that has changed its product lines and introduced new elements in accessories and designs to attract urban young people in India today.

\section{OBJECTIVES}

A study to evaluate the level of satisfaction of customer on using Fast track watches With Special Reference to Perambur Taluk

1. To explore the reason for the purchase of Fast track watches by the customer[4]-[6] .

2. To evaluate the various factors which has influenced the satisfaction of Fast track watches

3. To suggest various way to improve the performance of Fast track watches.

\section{A. Scope of the Study}

The work on Fast track Watches with respect to consumer satisfaction aims at finding out the

Revised Manuscript Received on December 11, 2019

J. Kannan, Department of Science and Humanities, Bharath Institute of Higher Education and Research, Chennai , India. Email: sjkannan1986@gmail.com

D. Venkatrama Raju, Department of Science and Humanities, Bharath Institute of Higher Education and Research, Chennai, India. Email: prof.dvraju@gmail.com protectoral and expectation of Fast track in market with special reference to perambur taluk.

To know about the strength and weakness of the victory product available in the market.

This project has the importance of additional features in the watches, finally the study attempts to find out the opinion about the sales, price and quality of product with regard to Fast track watches[7]-[9].

The study by ascertaining the factors that motivates and end-user to purchase Fast track Watches enables the company to channels its service, Advertisement Company' s accordingly. Consumer' s expectations are also gauged to help the company in proactive strategy formulations.

\section{RESEARCH METHODOLOGY}

The validity of research depends primarily on the proper collection of data from the method and the appropriate analytical technique[10]-[14].

\section{A. Research Design}

The research design is the arrangement of the data collection and analysis condition in a manner that helps to combine relevance to the research purpose with the process economy. The design used in the study is the type of description. It includes surveys, findings of facts, inquiries. The main purpose of this research is to identify the current state of affairs.

\section{Primary data}

The study is based primarily on primary data. First-hand information is gathered through a well-structured survey. Convenient sampling method is adopted in the selection of respondents. Information is obtained from the sample of 100 respondents.

\section{Secondary data}

Secondary data includes various topic-related information, journals, newspapers, and management.

\section{B. Limitations of the study}

$>$ The study is restricted only to Perambur Taluk and the results of the study can not therefore be generalized to other areas[15]-[17]. 


\section{Advances in Quality of Fastrack Watches Upon Introducing Automated Machinaries}

The time duration for the study was short period.

\section{RESULTS AND DISCUSSION}

The greater parts of the assenters are male (52\%).

$4 \%$ of the assenters belongs to $18-20$ years, $12 \%$ of the respondents belongs to 21-25 years. $21 \%$ respondents belongs to 26-30 years and remaining $63 \%$ of the respondents belongs to above 30 years of age group

$4 \%$ of the assenters belongs to $18-20$ years, $12 \%$ of the assenters belongs to 21-25 years. $21 \%$ assenters belongs to $26-30$ years and remaining $63 \%$ of the assenters belongs to above 30 years of age group

$3 \%$ of the assenters are illiterate level education. $18 \%$ of the respondents are school level. 59\% respondents are under graduate level and remaining $59 \%$ of the respondents are in post graduate level of education

$47 \%$ of the assenters are married and $53 \%$ of the respondents are unmarried.

$23 \%$ of the assenters are students and $27 \%$ of the respondents are employees and 50\% respondents are Business / Professions out of 100 respondent

$7 \%$ of the assenters are earning upto Rs.5000 per month, $36 \%$ of the assenters are earning Rs.5000-Rs.10000 per month, 30\% of the assenters are earning Rs.10000 Rs. 15000 per month and remaining $27 \%$ of the assenters are earning above Rs. 15000 per month out of 100 respondents.

$78 \%$ of the assenters are wear Fast track watches and $22 \%$ of the respondents are non user of Fast track watches $28 \%$ of the respondents are purchase leather watch and $72 \%$ of the respondents are purchase Chain watch.

$23 \%$ of the respondents are purchase Eco-Drive model, $41 \%$ of the respondents are purchase Cristal model, $20 \%$ of the respondents are purchase office wear model and remaining $16 \%$ of the respondents are purchase Super Fibre model out of 100 respondents.

$37 \%$ of the respondents using the product is below 1 year. $23 \%$ of the respondents using the products periods are 1-2 years. Then $17 \%$ respondents using product is $2-5$ years. $13 \%$ of the respondents using the product is above 5 years.

$40 \%$ of the respondents are giving their opinion as good, $32 \%$ of the respondents are giving their opinion as excellent, $15 \%$ of the respondents are giving their opinion as comfortable and remaining $13 \%$ of the respondents are says not bad out of $100 \%$ of the respondents.

$6 \%$ of the respondents are purchase Fast track for their reasonable price, $56 \%$ of the respondents are purchase for attractive models, $33 \%$ of the respondents are says quality of product and remaining $5 \%$ of the respondents are say the warranty of the product is attract for purchase this brand

$38 \%$ of the assenters are purchase Fast track by friends advice, $46 \%$ of the assenters are purchase by attractive advertisement in TV. $3 \%$ of the respondents are motivated by relatives and remaining $13 \%$ of the respondents are pursing Fast track by own desire.

$18 \%$ of the respondents are giving their opinion as good about advertisement of Fast track watch, $26 \%$ of the respondents are giving their opinion as attractive, $41 \%$ of the respondents are giving their opinion as fair and remaining $15 \%$ of the respondents are says poor about advertisement of Fast track watch out of $100 \%$ of the respondents.

$100 \%$ of the respondents are says they get warranty from the retailers.

$55 \%$ of the respondents are highly satisfied with warranty of product, $36 \%$ of the respondents are satisfied $6 \%$ of the respondents are partially satisfied and remaining $3 \%$ of the respondents are dissatisfied with warranty of Fast track Watch[18]-[21].

$35 \%$ of the assenters are says Fast track watches have reasonable price, $30 \%$ of the assenters are says fair, $16 \%$ of the respondents are says too costly and remaining $19 \%$ of the respondents are say not reasonable price of the Fast track watch out of $100 \%$ respondents

$3 \%$ respondents are gives their opinion to switch to another brand. $97 \%$ of the respondents are says No.

$13 \%$ of the respondents prefer HMT, $360 \%$ of the respondents are prefer Sonata, $18 \%$ of the respondents are prefer Timex, and 33\% of the respondents are prefer Wrist.

$10 \%$ respondents are gives their opinion to innovative model are better than the existing model remaining $90 \%$ of the respondents are say No.

The greater parts of the assenters are satisfied towards price of Fast track Watch of $42 \%$.

The greater parts of the assenters are highly satisfied towards quality of Fast track Watch of $72 \%$.

The greater parts of the assenters are satisfied towards offers given by Fast track Watch of $41 \%$.

The greater parts of the assenters are satisfied towards services given by Fast track Watch of i.e $38 \%$.

The greater parts of the assenters are Highly satisfied towards style given by Fast track Watch of i.e 39\%.

It is conclude that majority of the respondents were given by the first rank are

Published By.

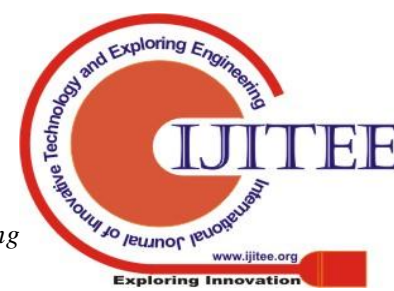


branded name were influenced of the respondents.

It is noted that, in terms of the overall Satisfaction score, The significance point value was less than 0.05 (5 percent level) and the null hypothesis was therefore dismissed.It is seen that gender factor had influenced the level of satisfaction score of customers towards Fast track Watch.

It is noted that, in terms of the overall Satisfaction score, The significance point value was less than 0.05 (5 percent level) and the null hypothesis was therefore dismissed. It is seen that age factor had influenced the level of satisfaction score of customers towards Fast track Watch.

It is noted that, in terms of the overall Satisfaction score, The significance level value was higher than 0.05 ( 5 percent level) and the null hypothesis was therefore conventional. It is seen that educational factor had not influenced the level of satisfaction score of customers towards Fast track Watch[22]-[23].

It is noted that, in terms of the overall Satisfaction score, The significance level value was higher than 0.05 ( 5 percent level) and the null hypothesis was therefore conventional. It is seen that marital status factor had not influenced the level of satisfaction score of customers towards Fast track Watch.

It is noted that, in terms of the overall Satisfaction score, The significance level value was higher than 0.05 (5 percent level) and the null hypothesis was therefore conventional. It is seen that occupational factor had not influenced the level of satisfaction score of customers towards Fast track watch.

It is noted that, in terms of the overall Satisfaction score, The significance level value was higher than 0.05 ( 5 percent level) and the null hypothesis was therefore conventional. It is seen that income factor had not influenced the level of satisfaction score of customers towards Fast track watch.

It is noted that, in terms of the overall Satisfaction score, The significance level value was higher than 0.05 (5 percent level) and the null hypothesis was therefore conventional. It is seen that Model of purchase factor had not influenced the level of satisfaction score of customers towards Fast track watch.

It is noted that, in terms of the overall Satisfaction score,

The significance level value was higher than 0.05 ( 5 percent level) and the null hypothesis was therefore conventional. It is seen that family size factor had not influenced the level of satisfaction score of customers towards Fast track watch.

It is noted that, in terms of the overall Satisfaction score, The significance point value was less than 0.05 (5 percent level) and the null hypothesis was therefore dismissed. It is seen that influence to buy the brand factor had influenced the level of satisfaction score of customers towards Fast track watch.

It is ended that no significant relationship exists between opinion about Fast track brand watch and preference of other brand watches[24].

It is concluded that there is no significant relationship between how long brand usage of fastract watch and opinion about Fast track watch product.

It is concluded that there is no significant relationship between preference of other branded watches and attitude about price of Fast track watch.

\section{SUGGESTIONS}

- These suggestions are given to the betterment of the brand in various departments of the marketing like, sales promotion.

- The manufacturers must see that the qualities of the watches are superior.

- Additional facilities offered must be competing with each other.

- Prices must be fixed at a nominal rate so that people of all classes are benefited.

- More offers should be given to the consumers in order to complete with the rival products[25].

- In the recent days there are some controversies, that continuous usage is creating health disorder. So to detect this problem awareness program should be conducted for certain duration.

- Regarding the TV commercials the company should accept sponsorship for the sports. This will help in reachability of product in remote areas also. The circulation of the product and sales will be improved.

- The price level of the product is too expensive for the low budget people so reducing price level is increase to sales intensity.

\section{CONCLUSION}

Every model should give more importance to consumer satisfaction. If the degree of consumer satisfaction is more, they will recommended others to purchase the same brand. It will increase the reputation and sales volume of the organization. The consumers are able to provide information with regard to factors of dissatisfaction. It is very much useful to the Fast track Watch Company to rectify those factors.

The researcher's study concludes that the performances of Fast track Watch Company are good. To increase the sales the concern can concentrate on certain factors like price, spares and service etc.

\section{REFERENCES}

[1] Vasanthi, S. \& Rabiyathul Basariya, S. 2019, "Influence of value analysis and cross training in industry", International Journal of Engineering and Advanced 
Technology, vol. 8, no. 6, pp. 1810-1811.

[2] Velvizhi, R., Sri Gowtham, S. \& Jeya Priya, D. 2019, "Examination of early feedbacks for effective product retailing on E-commerce websites", International Journal of Engineering and Advanced Technology, vol. 8, no. 6 Special Issue 2, pp. 703-706.

[3] Anuradha, C., Pothumani, S. \& Kavitha, R. 2019, "A novel method towards E-commerce", International Journal of Engineering and Advanced Technology, vol. 8, no. 6 Special Issue 2, pp. 535-538.

[4] Thomas, J. \& Rabiyathul Basariya, S. 2019, "A study on the issues of financial ratio analysis", Indian Journal of Public Health Research and Development, vol. 10, no. 3, pp. 1079-1081.

[5] Ramachandran, S. \& Rabiyathul Basariya, S. 2019, "Online marketing study on customer satisfaction and relationship", Indian Journal of Public Health Research and Development, vol. 10, no. 3, pp. 1072-1078.

[6] Priya, R., Vinothini, G. \& Cor Jesu, C.D. 2019, "The mentor-protégé relationship for professional growth", Journal of Advanced Research in Dynamical and Control Systems, vol. 11, no. 9 Special Issue, pp. 1110-1119.

[7] Jannifer Rani, N., Bina Pani, S. \& Nimisha, N.S. 2019, "A study on money back polices available in LIC", Journal of Advanced Research in Dynamical and Control Systems, vol. 11, no. 9 Special Issue, pp. 833-839.

[8] Saillaja, V., Jhansi Rani, K. \& Catherine, R. 2019, "Global marketing management planning and organization", Journal of Advanced Research in Dynamical and Control Systems, vol. 11, no. 9 Special Issue, pp. 489-493.

[9] Saillaja, V., Jhansi Rani, K. \& Catherine, R. 2019, "The new phase of marketing information system", Journal of Advanced Research in Dynamical and Control Systems, vol. 11, no. 9 Special Issue, pp. 482-488.

[10]Thoufiqulla \& Raju, D.V. 2019, "Perception of indian investor towards investment in mutual funds with special reference to mip funds", Journal of Advanced Research in Dynamical and Control Systems, vol. 11, no. 5, pp. 177-183.

[11]Jasmine, K.R.M. \& Basariya, S.R. 2018, "A study on the customers benefits on mutual funds", International Journal of Civil Engineering and Technology, vol. 9, no. 4, pp. 45-48.

[12]Vasanthi, S. \& Basariya, S.R. 2019, "Pros and cons of on the job training versus off the job training", International Journal of Scientific and Technology Research, vol. 8, no. 10, pp. 671-674.

[13]Pavithra, J. \& Ganesan, M. 2016, "A study on awareness and impact of micro-financial schemes", International Journal of Applied Business and Economic Research, vol. 14, no. 8, pp. 5449-5460.

[14]Pavithra, J., Dilli Babu, P. \& Ambuli, T.V. 2014, "A study on budgetary control at Maruti Service Masters, Chennai", International Journal of Applied Business and Economic Research, vol. 12, no. 2, pp. 151-161.

[15]Gunaraja, T.M. \& Venkatrama Raju, D. 2018, "Determining factors of organisational climate with reference to leadership styles", International Journal of Mechanical Engineering and Technology, vol. 9, no. 9, pp. 1327-1332.

[16]Gunaraja, T.M. \& Venkatrama Raju, D. 2018, "The role of job satisfaction and training of employees in determining organisational climate of a selected industry", International Journal of Civil Engineering and Technology, vol. 9, no. 8, pp. 1266-1269.

[17]Aarathy, T.S. \& Raju, D.V. 2018, "Performance appraisal and its effects on employees with respect to it sector in Chennai city", International Journal of Civil Engineering and Technology, vol. 9, no. 6, pp. 1535-1538.

[18]Aarathy, T.S. \& Raju, D.V. 2018, "Employee perception towards performance appraisal system in IT sector", International Journal of Mechanical Engineering and Technology, vol. 9, no. 5, pp. 131-135.

[19]Porselvi, W., Jublee, D. \& Sivanesan, G. 2018, "A study on factors influencing adoption of technology and innovation in banking industry, tamilnadu, India", International Journal of Mechanical Engineering and Technology, vol. 9, no. 5, pp. 789-800.

[20]Akessa, G.M. and Dhufera, A.G., 2015. Factors That Influences Students Academic Performance: A Case of Rift Valley University, Jimma, Ethiopia. Journal of Education and Practice, 6(22), pp.55-63.

[21]Miller, G. and Shih, C.C., 1999. A faculty assessment of the academic rigor of on-and off-campus courses in agriculture. Journal of Agricultural Education, 40, pp.57-65.

[22]Tsinidou, M., Gerogiannis, V. and Fitsilis, P., 2010. Evaluation of the factors that determine quality in higher education: an empirical study. Quality Assurance in education, 18(3), pp.227-244.

[23]Farooq, M.S., Chaudhry, A.H., Shafiq, M. and Berhanu, G., 2011. Factors affecting students' quality of academic performance: a case of secondary school level. Journal of quality and technology management, 7(2), pp.1-14.

[24]Fitsilis, P., Gerogiannis, V. and Anthopoulos, L., 2014. Ontologies for software project management: a review. Journal of Software Engineering and Applications, 7(13), p.1096.
[25]Adams, J.D. and Jaffe, A.B., 1996. Bounding the effects of R\&D: an investigation using matched establishment-firm data(No. w5544). National bureau of economic research.

\section{AUTHORS PROFILE}

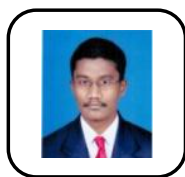

J.Kannan Associate Professor, Department of Science and Humanities, Bharath Institute of Higher Education and Research, Chennai, India.

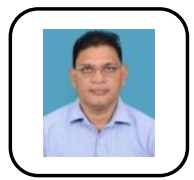

D. Venkatrama Raju Professor, Department of Science and Humanities, Bharath Institute of Higher Education and Research, Chennai, India. 